\title{
Brain Recognition and Sensibility Response according to the Shape of Eyes and Eyeshadow Tone
}

\author{
Min-Kyung Kim \\ Department of Beauty Care, Jangan University, Hwaseong-si, Gyeonggi-do, Korea
}

Corresponding author: Min-Kyung Kim, Department of Beauty Care, Jangan University, 1182 Samcheonbyeongma-ro, Bongdam-eup, Hwaseong-si, Gyeonggi-do 18331, Korea

Tel.: +82 312993316

Fax: +82 312993612

Email: minkyung4567@jangan.ac.kr

Received May 11, 2017

Revised August 27, 2017

Accepted September 8, 2017

Published December 30, 2017

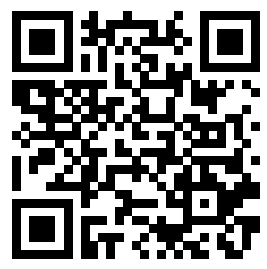

\begin{abstract}
Purpose: The aim of this study was to quantitatively evaluate the brain recognition response to the five shapes of eyes [standard eyes (SE), up-turned eyes (UE), downturned eyes (DE), small eyes (SmE), and big eyes (BE)] and to the alterations in the eyeshadow tones. Moreover, the correlation between sensibility response, five eyes shapes, and eyeshadow tones is investigated in order to be used as the scientific data of image making. Methods: Quantitative data was extracted with a brainwave measured as a stimulus to the five shapes of eyes and eyeshadow tones. The questionnaire was organized into a semantic differential 10-point scale ( -5 to 5 ). Results: The relative beta power (RB), relative gamma power (RG), spectral edge frequency 50 (SEF50), and SEF90, which are activated by vigilance and stimulation, demonstrated a significant increase in $\mathrm{UE}$ and $\mathrm{BE}$, whereas the relative alpha power (RA), which is activated by relaxation, was activated in SmE and DE. The brainwave reaction to the alterations in the eyeshadow tones activated the RB, RG, SEF50, and SEF90 from low brightness. Even if there is a little difference in the sensibility response output, then dark-grayish tone gets significantly evaluated as strong and heavy. Conclusion: The analysis represents that sensibility can be altered by varying the eyeshadow tones for makeup, thereby suggesting that physiological and emotional reactions appear higher depending on alterations in the eyeshadow tones than on the shapes of eyes. I suppose that it can be utilized as a quantitative database sample in image rendering by extracting physiological and emotional reaction results based on the shapes of eyes and alterations in the eyeshadow tones.
\end{abstract}

Keywords: Brain, Recognition, Sensibility, Shapes of eyes, Eyeshadow tones

\section{Introduction}

메이크업은 자신의 내적인 심리를 외적으로 표출하는 수단으 로서 정체성과 상호작용을 나타내는데 효과적이다(Lee, 2010). 특히 이미지는 헤어 스타일, 눈동자, 피부 색상, 메이크업 등에 따라 여러 가지 형태로 나타나지만, 이미지 형성에 가장 큰 역할 을 하는 수단은 메이크업이라 할 수 있다(Kim \& Ryu, 2004).

눈, 아이라이너, 눈썹의 형태에 따라 얼굴 이미지 형성에 변화 를 준다는 연구(Kim \& Ryu, 2011; Kim, 2014; Song \& Park, 2004; Yoo, 2011), 메이크업 색채를 이용하여 이미지 변화에 효과적으로 활용한 사실(Song \& Park, 2005; Yun \& Jung, 2016) 등의 선행연구들을 통하여 형태와 색상에 따라 이미지 변 화에 효과적임이 증명되었다. 또한, 아이쉐도우 톤과 색상 배
색 관계를 분석하기 위하여 먼셀(Munsell)의 베이직 컬러 차트 (basic color chart)를 바탕으로 채도와 명도를 제시하여 색의 배 색 관계(Ji \& Kim, 2016)를 연구한 선행연구가 있었으며, 일러 스트레이션 얼굴이미지를 활용하여 메이크업 배색 표현이 과학 적으로 활용 가능하다는 연구결과(Han, 2015)도 보고되었다. 그 러나 아직 눈의 형태나 메이크업 톤에 대한 컬러 표현방법은 정 성적 방법인 통계방법으로 이루어져 있어(Kim \& Ryu, 2011; $\mathrm{Kim}$ et al., 2015; Kim, 2011), 과학적 데이터 활용으로는 부족 하였다.

몇몇 선행연구에서 메이크업 색상과 톤 변화를 이용한 이미 지 연출과 활용법이 과학적으로 이루어지고 있으나 극소수였다. 일부 선행 연구들 중 과학적 표현방법으로 컬러의 효과를 증명 하였고(Jin et al., 2012; Knez, 2001; Lee \& Lee, 2012), 색 
이미지를 활용한 연구(Ahn \& Kim, 2013; Kim, 2016; You \& Kwak, 2010), 색 자극을 통한 스트레스지수를 생체신호 반응으 로 측정한 연구(Shahbazi et al., 2011; Strochlic \& Romero, 2008; Yildirim et al., 2011) 등의 색상 자체에 대한 연구가 대 부분이었으며 메이크업 색상에 대한 연구는 미미하였다. 색상에 관한 정량적 연구분야로는 인테리어 디자인 분야에서나 과학적 연구방법으로 해석하였으나, 메이크업 색상의 인지 정도는 소수 의 인원을 대상으로 설문에 의존하는 정성적 평가가 대부분이었 다. 이러한 평가들은 메이크업 색상이미지나 감성반응에 대한 결 과를 객관화하기에 다소 부족하였다.

따라서 본 연구는 눈의 형태를 구분하여 아이쉐도우 색상을 먼 셀 표기법으로 정량적으로 표현하였고, 눈의 형태와 아이쉐도우 톤 변화에 따른 생리 - 감성적 반응결과를 파악하여 이미지 연출 시 정량적 데이터 근거 표본으로 활용할 수 있을 것으로 사료된 다.

\section{Methods}

\section{1. 실험재료}

본 연구에서 표준형 눈(standard eyes, $\mathrm{SE}$ )을 기준으로 눈 꼬리가 올라간 눈(up-turned eyes, UE), 눈꼬리가 내려간 눈 (down-turned eyes, $\mathrm{DE}$ ), 작은 눈(small eyes, $\mathrm{SmE}$ ), 큰 눈 (big eyes, BE)으로 Adobe Photoshop CS6 (Adobe Systems,

Table 1. Five shapes of eyes used as stimuli

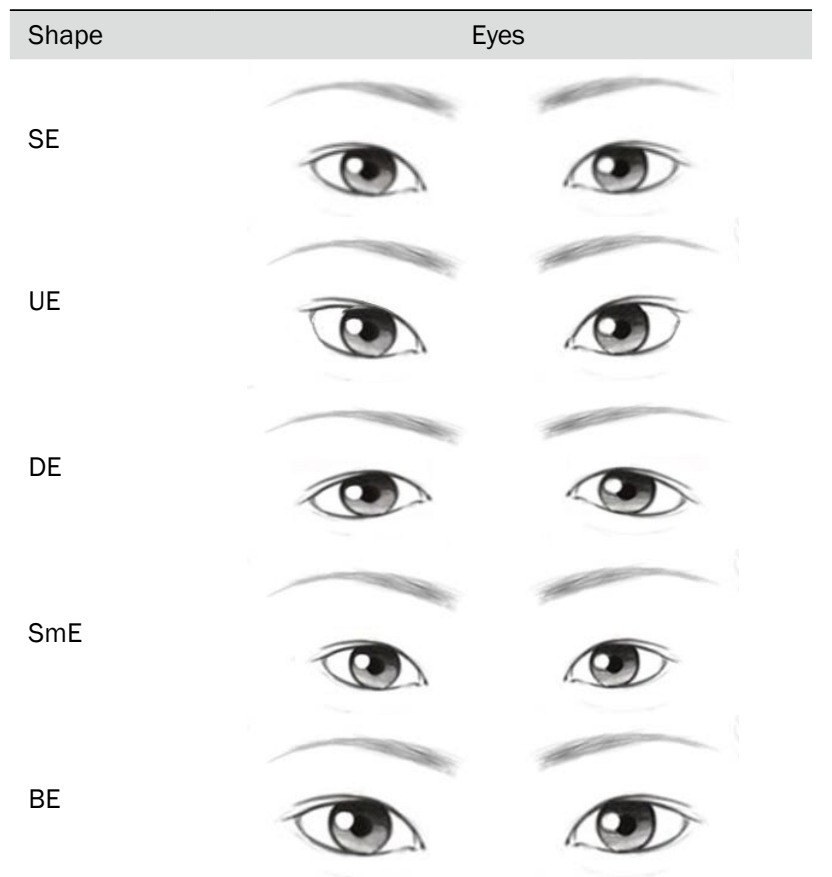

SE, standard eyes; UE, up-turned eyes; DE, down-turned eyes; SmE, small eyes; BE,big eyes.
$\mathrm{USA}$ )을 이용하여 자극물을 변형하였다(Table 1). SE를 기준으 로 $\mathrm{UE}$ 와 $\mathrm{DE}$ 는 눈꼬리 부분을 5 도씩 변형을 주었으며, $\mathrm{SmE}$ 와 $\mathrm{BE}$ 는 상하좌우 모두 $0.2 \mathrm{~cm}$ 씩 조절하여 자극물을 제작하였다. 뇌파 측정시 아이쉐도우 컬러에 따른 반응만을 보기 위하여 외 부자극인 피부색과 입술을 배제시켰고 눈과 눈썹만을 자극물로 제시하여 피험자를 대상으로 측정하였다. 우리나라 여성들이 가 장 선호하는 갈색, 베이지, 브라운 계열의 색상(Hong \& Kim, 2012)을 이용하여 톤 그라데이션으로 변화를 주었다. 변형된 각 각의 눈들은 브라운 계열의 색상 3 가지[RGB $(255,204,102)$; RGB (108, 72, 0); RGB (34, 23, 0)] 색연필을 이용하여 톤 변 화를 주며 그라데이션 하였으며, 톤 변화는 아무런 컬러를 적용 하지 않은 눈(no makeup)으로 시작하여 4단계로 컬러링하여 총 5단계의 톤(no makeup; light-grayish tone; grayish tone; dark tone; dark-grayish tone)으로 제작하였다(Table 2).

\section{2. 실험대상 및 뇌파 측정방법}

서울, 경기도 소재의 전문대학과 대학교에서 뷰티과정을 전공

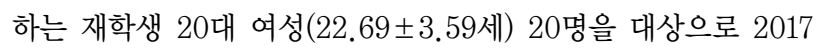
년 4월 10 일부터 4 월 30 일까지 실험을 진행하였다. 피험자들은 Beck depression inventory (BDI) 측정을 통하여 신경학 또는 정신질환 병력이 없으며, 색맹이 아니고 인지 장애가 없는 대상 만을 선발하였다. 본 연구는 헬싱키윤리기준과 임상시험기준을 준수했으며, 숭실대학교 연구윤리위원회의 승인 하에 이루어졌 고 모든 피험자에게 충분한 설명 후 동의를 구하였다(승인번호: SSU-201404-HR-016-01).

피험자에게 눈 일러스트를 한 실제 자극물을 $60 \mathrm{~cm}$ 거리에 서 놓고 보여주어 $20 \mathrm{~s}$ 간 뇌파를 측정하였다. 뇌파 생리신호 (electroencephalogram, EEG)는 QEEG 32 system (Laxtha, Korea)을 사용하여 측정하였고 뇌파 측정 부위는 국제 10-20 전 극배치법의 기준에 따라 21 부위 $(\mathrm{Fp} 1, \mathrm{Fpz}, \mathrm{Fp} 2, \mathrm{~F} 3, \mathrm{~F} 4, \mathrm{~F} 7$, F8, Fz, T3, T4, C3, C4, Cz, P3, P4, Pz, T5, T6, O1, Oz, $\mathrm{O} 2$ )에 부착하여 단극 유도법으로 측정했다. 안구 움직임이나 안 면근육 수축 등과 같은 몸의 움직임이 없음에도 불구하고 바탕 뇌파의 변동이 심한 피험자는 배제시켰고 정상적인 바탕 뇌파가 측정된 피험자를 대상으로 하였다. 뇌파 측정 전 피험자가 안정 상태를 유지하도록 눈을 감은 채 2-3 $\mathrm{min}$ 동안 명상을 취한 후 편안한 상태에서 눈을 뜨고 색상 자극물이 있는 종이를 $20 \mathrm{~s}$ 동 안 응시하도록 하며, 자극물을 보는 동안 뇌파를 수집하였다. 시 각반응에 관한 뇌파 측정방법은 한번만 짧게 제시하여 뇌에 잔상 이 남아 있지 않도록 측정한다. 자극물을 보고 있는 동안 눈의 깜 빡임의 데이터는 처리과정에서 제거하였다. 피험자에게 자극물 의 순서는 무작위로 하였고, 뇌파 측정 후 바로 감성반응을 체크 하였다. 


\section{3. 감성평가}

다섯 가지 눈의 형태 이미지와 톤 변화에 따른 감성용어를 어 의차이척도 10 point scale ( -5 to 5 )로 사용하여 설문 문항을 구 성하였으며, 감성반응은 형용사 이미지 스케일에 나오는 단어 를 이용하여 구성하였다. 감성형용사는 hard-soft, dynamicstatic, mannish-feminine, strong-weak, gloomybrilliant, dark-bright, heavy-light, active-silent로 8쌍 을 구성하였다. 감성형용사는 Kim \& Ryu (2011)의 선행연구와 image research institute (IRI)의 이미지 형용사 스케일에서 사 용한 단어를 추출하였다.

\section{4. 분석방법}

각 눈의 다섯 가지 형태와 톤 변화에 따른 뇌파분석은 수집된 뇌파 데이터를 프로그램으로 분석하여 정량적 데이터를 획득하 였다. 0-50 Hz의 주파수 영역 중 눈 굴림이나 안면 근육의 움직 임에 따라 영향을 많이 받는 delta $(0-4 \mathrm{~Hz})$ 를 제거한 후 fast fourier transform (FFT)의 알고리즘을 이용하여 나머지 주파 수 대역 $(4-50 \mathrm{~Hz})$ 의 파워 스펙트럼을 분석하였다. 전체 주파수 대역의 상대 파워값(relative power values, RPVs)인 가수면상 태에서 활성되는 상대 세타파(relative theta power, RT; 4-8 $\mathrm{Hz}$, 이완시 활성하는 상대 알파파(relative alpha power, RA; 8-13 Hz), 각성시 출현하는 상대 베타파(relative beta power, $\mathrm{RB} ; 13-30 \mathrm{~Hz})$, 집중시 출현하는 상대 감마파(relative gamma power, $\mathrm{RG} ; 30-50 \mathrm{~Hz}$ )를 측정하였으며, $13-15 \mathrm{~Hz}$ 대역의 뇌 파로 각성시 활성되는 상대감각운동리듬(relative sensorimotor rhythm, RSMR), 산만하고 부주의시 활성되는 세타파(4-50 $\mathrm{Hz})$ /느린베타 $(12-20 \mathrm{~Hz})$ 를 분석한 $1 /$ ratio of sensorimotor rhythm-mid beta to theta (1/RSMT), 모서리 주파수(spectral edge frequency, SEF)인 SEF50과 SEF90을 분석하였다(Kang et al., 2013). 아무런 자극이 없는 바탕 뇌파의 RPVs 대비 다
섯 가지 눈 형태와 톤 변화에 따른 RPVS와 바탕 뇌파의 상대 뇌 파 파워 차이의 비율인 뇌파변동계수(coefficient of variation for the brainwave; CVB)를 분석하였다. 각 자극에 대한 모 서리 주파수의 변화는 바탕 뇌파의 평균값 대비 각 자극에 대 한 모서리 주파수 값의 편차로 평가하였다(Jung et al., 2015; Kang et al., 2013). 뇌파 반응에 대한 통계 분석과 감성반응 은 Statistical Package for the Social Sciences (SPSS) ver. 22.0 (IBM, USA)을 사용하여 반복측정 분산분석(repeated measure analysis of variance)을 실시하였고, $95 \%$ 신뢰수준 에서 Tukey's test를 통해 사후검증을 하였다.

\section{Results}

\section{1. 눈의 형태에 따른 뇌파변동계수}

표준형 눈(SE), 눈꼬리가 올라간 눈(UE), 눈꼬리가 내려간 눈 $(\mathrm{DE})$, 작은 눈 $(\mathrm{SmE})$, 큰 눈 $(\mathrm{BE})$ 을 자극물로 제시하여 얻은 뇌파 측정 결과를 바탕 뇌파의 상대 뇌파 파워 차이의 비율인 뇌파변 동계수(CVB)로 추출하였다(Figure 1).

졸리거나 가수면 상태에서 많이 관찰되는 $\mathrm{RT}$ 의 $\mathrm{CVB}$ 는 $\mathrm{DE}$ 에서 가장 크게 활성되었으며 $\mathrm{SE}>\mathrm{BE}>\mathrm{SmE}>\mathrm{UE}$ 의 순으로 도출 되었다(Figure $1 \mathrm{~A}$ ), 편안하고 이완 상태일 경우 활성되는 $\mathrm{RA}$ 의 $\mathrm{CVB}$ 는 $\mathrm{SmE}$ 에서 가장 활성되었으며 $\mathrm{DE}>\mathrm{SE}>\mathrm{UE}>\mathrm{BE}$ 순이 었다. 외부자극에 주의를 기울이고 활발한 사고시 출현하는RB 의 $\mathrm{CVB}$ 는 $\mathrm{BE}$ 에서 가장 활성되었으며 $\mathrm{UE}>\mathrm{SmE}>\mathrm{DE}>\mathrm{SE}$ 순이었 다. 복잡한 문제해결, 집중시 출현하는 $\mathrm{RG}$ 의 $\mathrm{CVB}$ 는 $\mathrm{UE}$ 에서 가 장 많이 상승하였고 $\mathrm{BE}>\mathrm{SE}>\mathrm{DE}>\mathrm{SmE}$ 순으로 활성되었다. $\mathrm{SE}$ 에

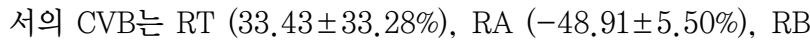
$(22.89 \pm 13.81 \%), \mathrm{RG}(50.38 \pm 41.56 \%)$ 로 도출되었다. $\mathrm{SE}$ 에 비 하여 $\mathrm{DE}$ 의 $\mathrm{RA}$ 는 $-48.59 \pm 7.18 \%$ 로 도출되었다. $\mathrm{SmE}$ 는 다른

Table 2. Eyeshadow tones of individual eye shapes

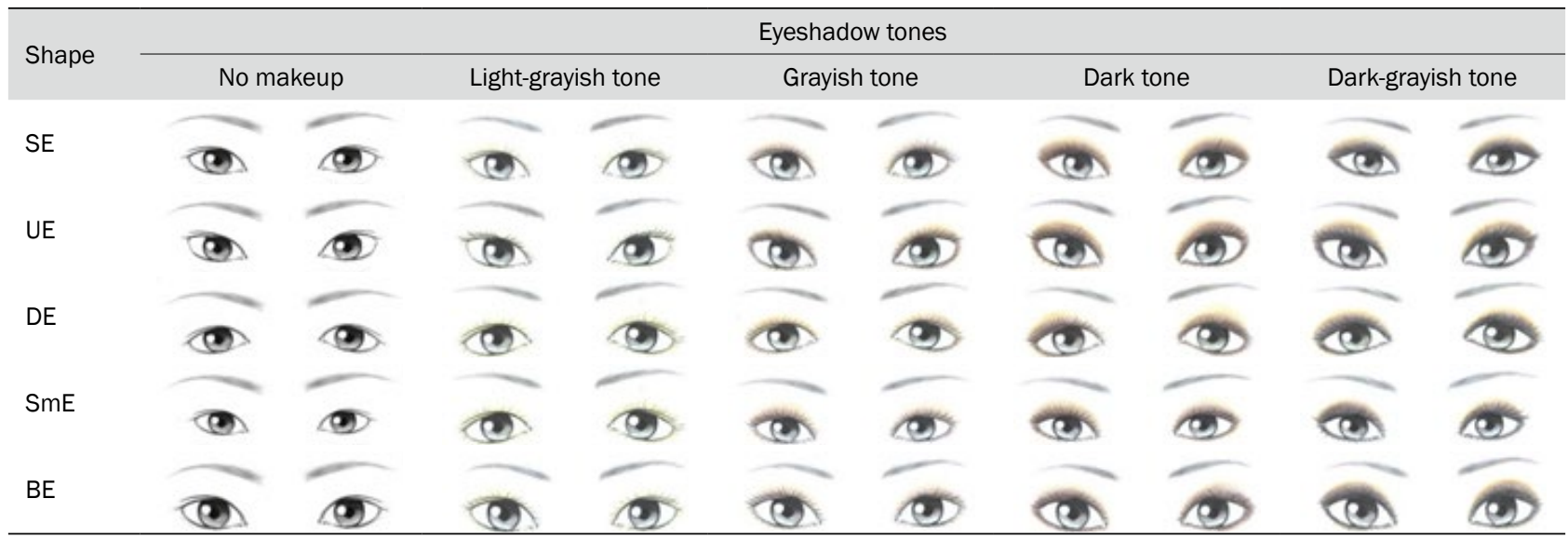

$\mathrm{SE}$, standard eyes; UE, up-turned eyes; DE, down-turned eyes; SmE, small eyes; BE, big eyes. 

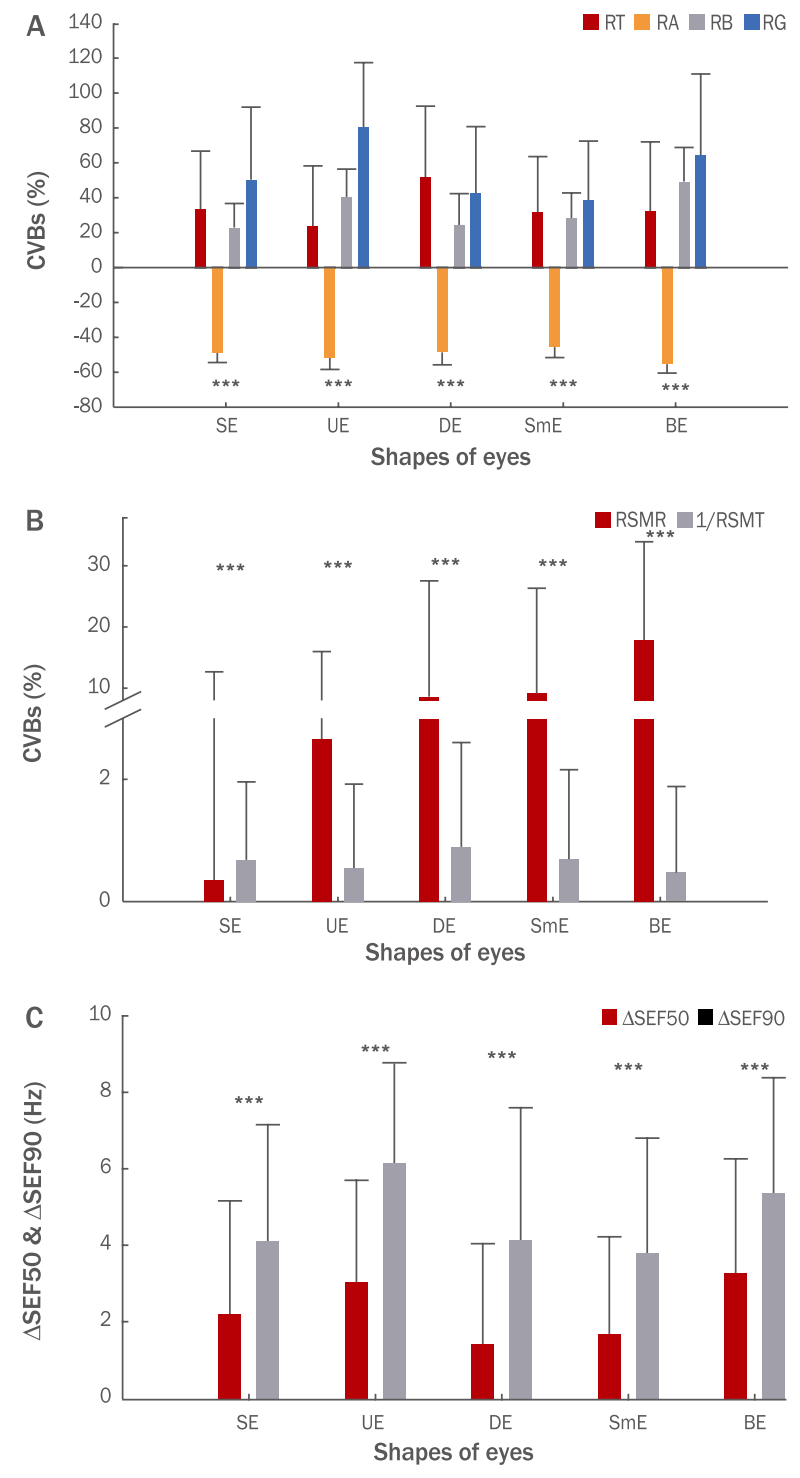

Figure 1. Variation factor of the brainwave by eyes shapes.

SE will be marked as the standard to measure the brainwave after observing the shapes of eyes as a stimuli. The result of the statistical significance according to alterations in the shapes of eyes is shown. (A) CVBs on RT, RA, RB, and RG for the five shapes of eyes. (B) CVBs on RSMR and 1/RSMT for the five shapes of eyes. (C) $\triangle$ SEF50 and $\triangle$ SEF90 for the five shapes of eyes. SE, standard eyes; UE, up-turned eyes; DE, down-turned eyes; SmE, small eyes; $\mathrm{BE}$, big eyes; CVB, coefficient of variation for the brainwave; RT, relative theta power; RA, relative alpha power; RB, relative beta power; RG, relative gamma power; RSMR, relative sensorimotor rhythm; RSMT, ratio of sensorimotor rhythm-mid beta to theta; SEF, spectral edge frequency; ${ }^{* * *} p<0.000$.

눈 형태에 비하여 $\mathrm{RG}(42.68 \pm 38.05 \%)$ 가 가장 적게 활성되었 다.

과잉행동이나 충동성 등의 행동이 적을 때 활발하게 출현하 는 $\mathrm{RSMR}$ 은 $\mathrm{BE}$ 에서 $17.88 \pm 17.46 \%$ 로 가장 많이 활성되었고,
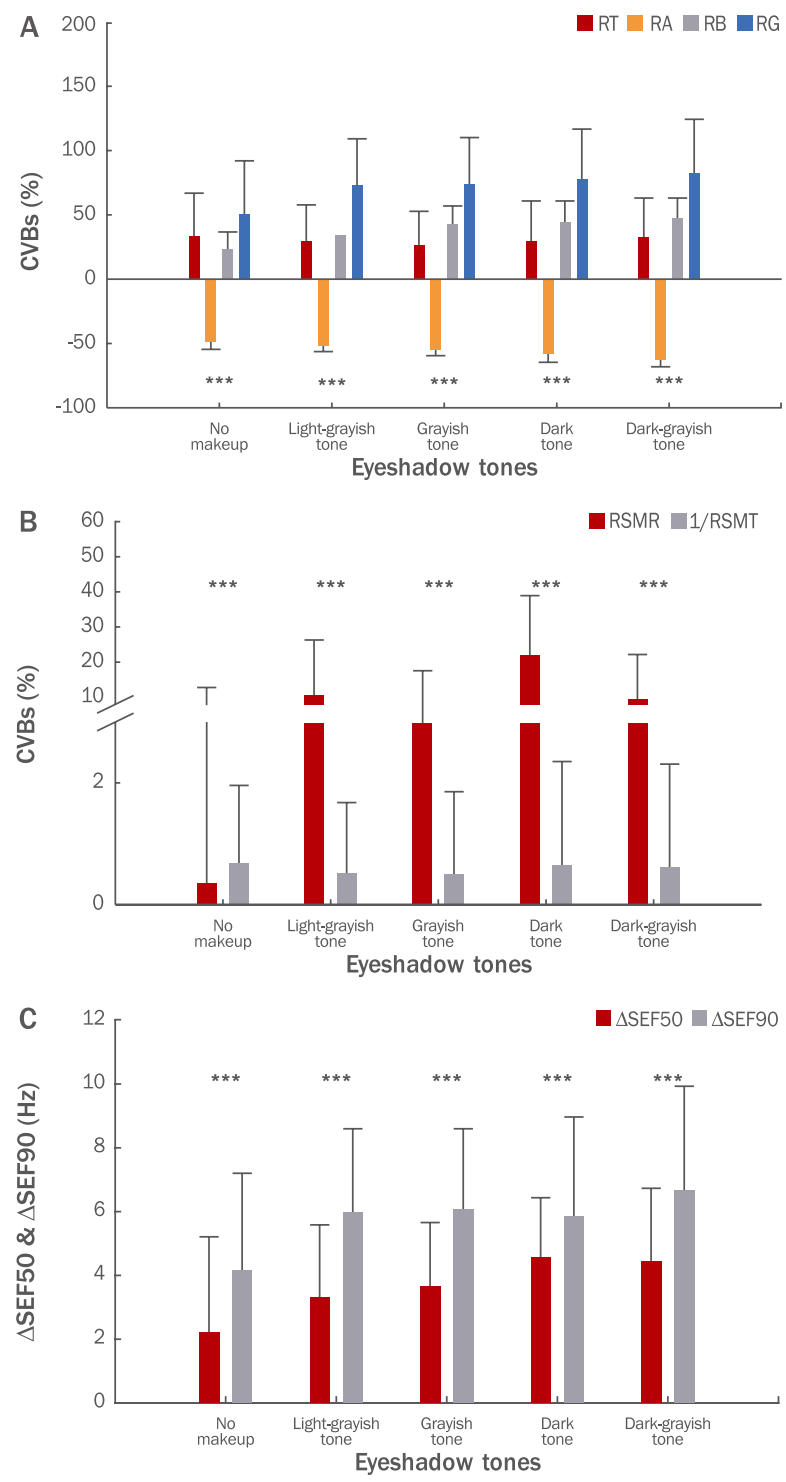

Figure 2. Variation factor of the brainwave according to alterations in the eyeshadow tones in SE.

This result is the brainwave according to stimulus by changing the brightness in SE 5 levels (no makeup, light-grayish tone, grayish tone, dark tone, and dark-grayish tone). The result of the statistical significance according to alterations in eyeshadow tones in SE is shown. (A) CVBs on RT, RA, RB, and RG for the eyeshadow tones in SE. (B) CVBs on RSMR and 1/RSMT for the eyeshadow tones in SE. (C) $\triangle$ SEF50 and $\triangle$ SEF90 for the eyeshadow tones in SE. SE, standard eyes; CVB, coefficient of variation for the brainwave; RT, relative theta power; RA, relative alpha power; RB, relative beta power; RG, relative gamma power; RSMR, relative sensorimotor rhythm; RSMT, ratio of sensorimotor rhythm-mid beta to theta; SEF, spectral edge frequency; ${ }^{* * *} p<0.000$.

$\mathrm{SmE}>\mathrm{DE}>\mathrm{UE}>\mathrm{SE}$ 순으로 도출되었다(Figure 1B). 산만하고 집 중을 못할 때 증가되는 $1 / \mathrm{RSMT}$ 는 $\mathrm{BE}$ 의 자극시 $0.47 \pm 1.41 \%$ 로 가장 낮게 반응하였다. $\triangle \mathrm{SEF} 50$ 은 $\mathrm{BE}$ 의 자극에서 가장 크게 출 

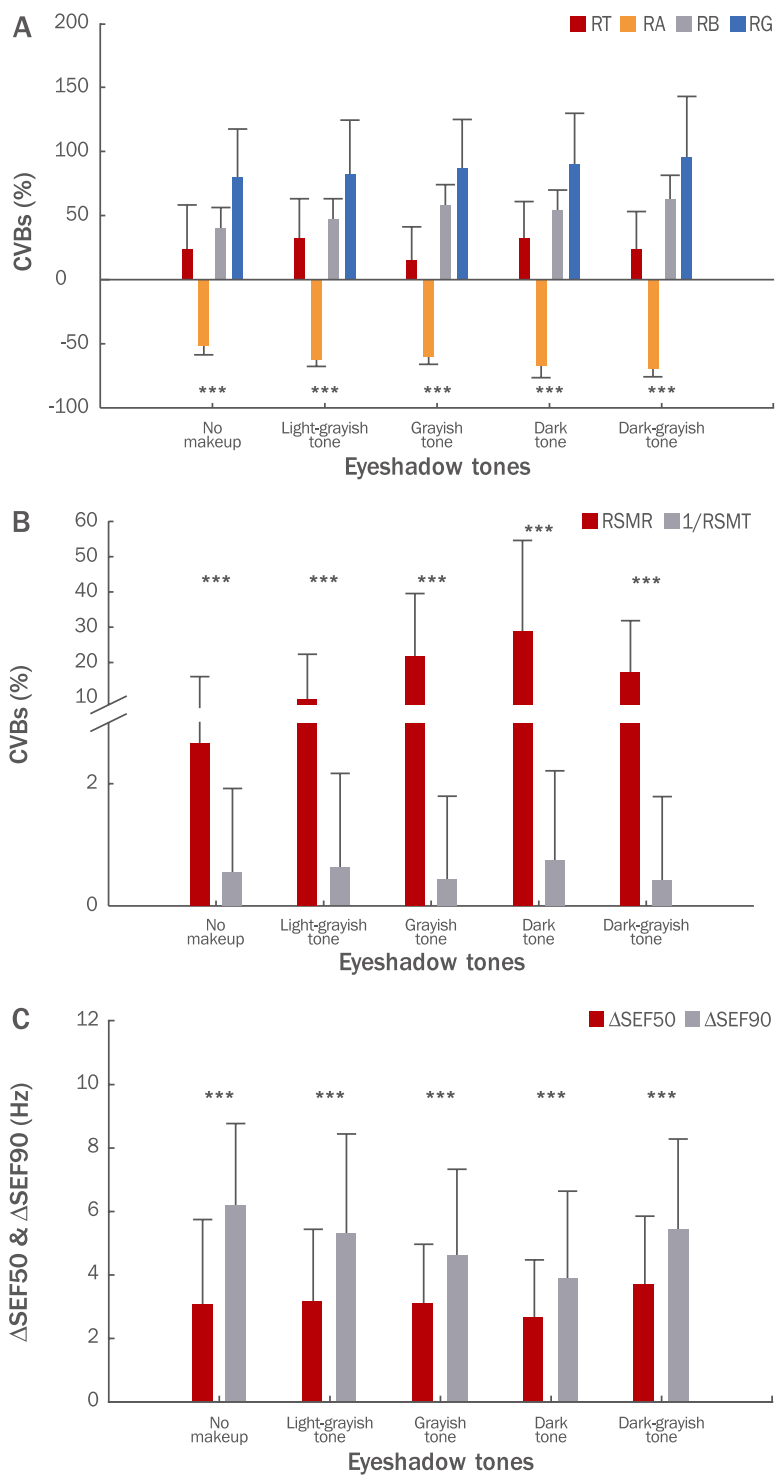

Figure 3. Variation factor of the brainwave according to alterations in the eyeshadow tones in UE.

This result is the brainwave according to stimulus by changing the brightness in UE 5 levels (no makeup, light-grayish tone, grayish tone, dark tone, and dark-grayish tone). The result of the statistical significance according to alterations in eyeshadow tones in UE is shown. (A) CVBs on RT, RA, RB, and RG for the eyeshadow tones in UE. (B) CVBs on RSMR and 1/RSMT for the eyeshadow tones in UE. (C) $\triangle$ SEF50 and $\triangle$ SEF90 for the eyeshadow tones in UE. UE, up-turned eyes; CVB, coefficient of variation for the brainwave; RT, relative theta power; RA, relative alpha power; RB, relative beta power; RG, relative gamma power; RSMR, relative sensorimotor rhythm; RSMT, ratio of sensorimotor rhythm-mid beta to theta; SEF, spectral edge frequency; ${ }^{* * *} p<0.000$.

현하였고 $\mathrm{UE}>\mathrm{SE}\rangle \mathrm{SmE}>\mathrm{DE}$ 순이었다(Figure $1 \mathrm{C}$ ). $\triangle \mathrm{SEF} 90$ 은 $\mathrm{UE}$ 의 자극에서 가장 활발하게 나타났고 $\mathrm{BE}>\mathrm{DE}>\mathrm{SE}>\mathrm{SmE}$ 순이 었다. $\mathrm{BE}$ 에서는 바탕 뇌파 대비 $\mathrm{SEF} 50$ 가 가장 활성이 많이 되
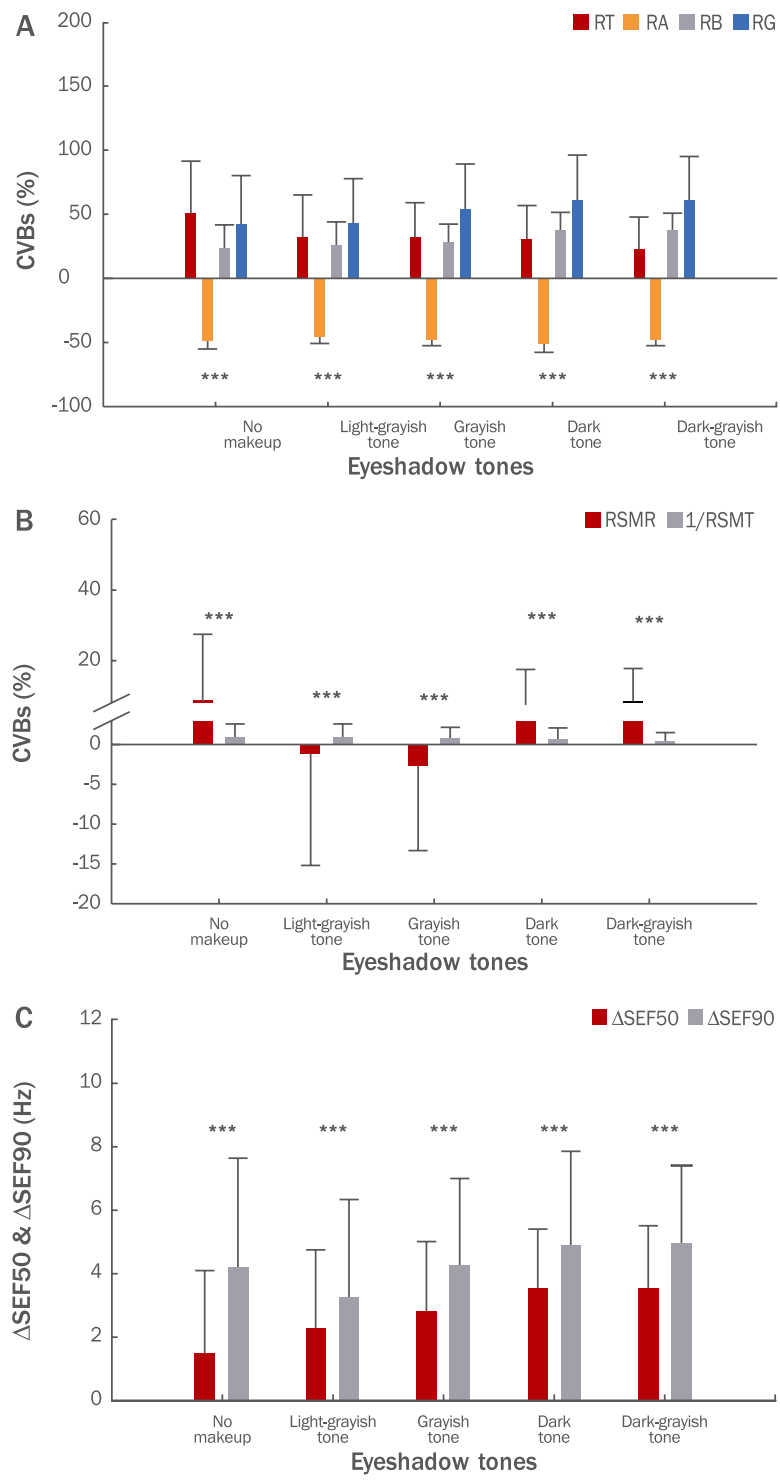

Figure 4. Variation factor of the brainwave according to alterations in the eyeshadow tones in DE.

This result is the brainwave according to stimulus by changing the brightness in DE 5 levels (no makeup, light-grayish tone, grayish tone, dark tone, and dark-grayish tone). The result of the statistical significance according to alterations in eyeshadow tones in DE is shown. (A) CVBs on RT, RA, RB, and RG for the eyeshadow tones in DE. (B) CVBs on RSMR and 1/RSMT for the eyeshadow tones in $\mathrm{DE}$. (C) $\triangle \mathrm{SEF} 50$ and $\triangle \mathrm{SEF90}$ for the eyeshadow tones in $\mathrm{DE}$. DE, down-turned eyes; CVB, coefficient of variation for the brainwave; RT, relative theta power; RA, relative alpha power; RB, relative beta power; RG, relative gamma power; RSMR, relative sensorimotor rhythm; RSMT, ratio of sensorimotor rhythm-mid beta to theta; SEF, spectral edge frequency; ${ }^{* * *} p<0.000$.

었으며, 자극적이며 스트레스를 받을 때 활성되는 SEF90은 UE 를 보았을 경우 가장 활성되었다. 따라서 $\mathrm{BE}$ 와 $\mathrm{UE}$ 의 자극시 집 중과 각성이 두드러졌으며 $\mathrm{SmE}$ 와 $\mathrm{DE}$ 의 자극시 안정감을 느끼 

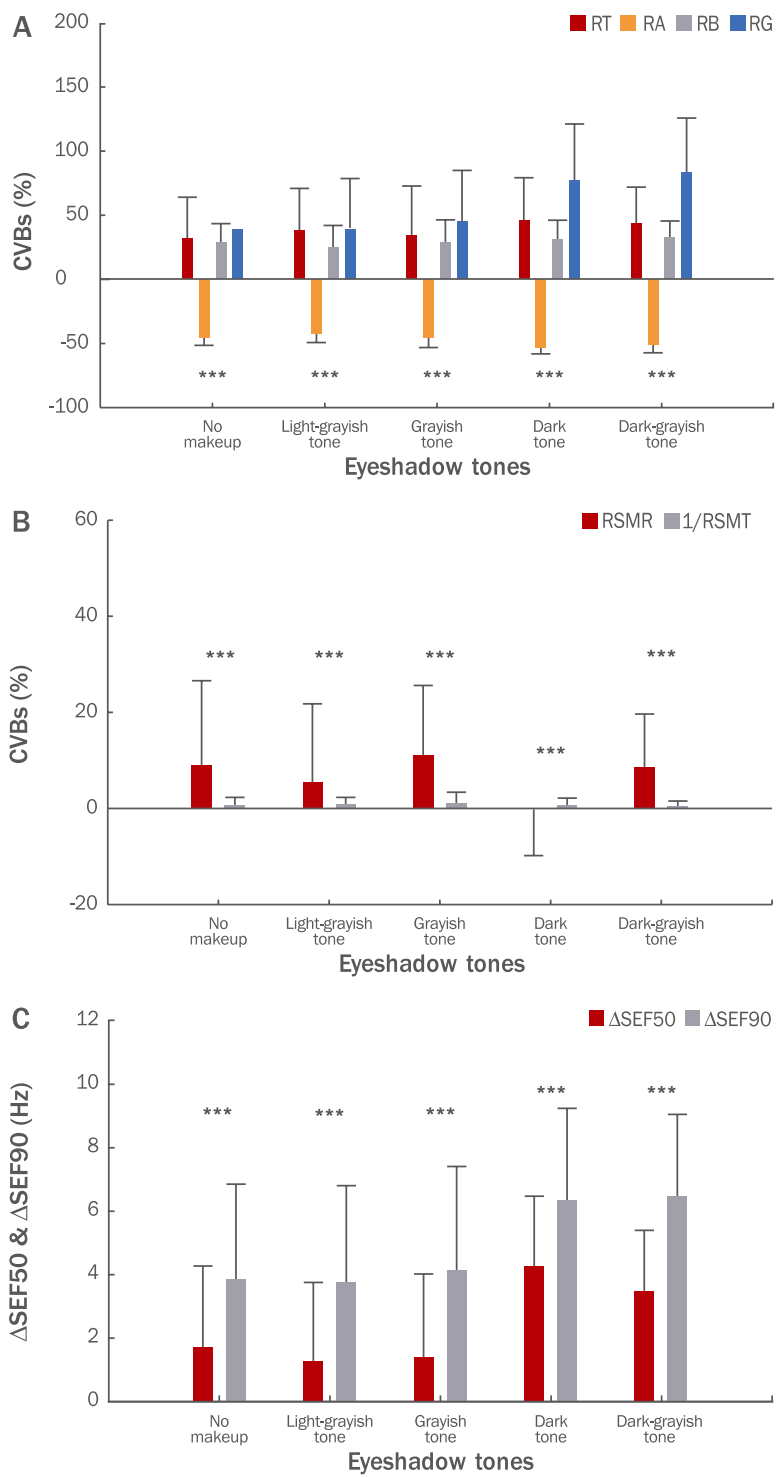

Figure 5. Variation factor of the brainwave according to alterations in the eyeshadow tones in SmE.

This result is the brainwave according to stimulus by changing the brightness in SmE 5 levels (no makeup, light-grayish tone, grayish tone, dark tone, and dark-grayish tone). The result of the statistical significance according to alterations in eyeshadow tones in SmE is shown. (A) CVBs on RT, RA, RB, and RG for the eyeshadow tones in SmE. (B) CVBs on RSMR and 1/RSMT for the eyeshadow tones in SmE. (C) $\triangle$ SEF50 and $\triangle$ SEF90 for the eyeshadow tones in SmE. SmE, small eyes; CVB, coefficient of variation for the brainwave; RT, relative theta power; RA, relative alpha power; RB, relative beta power; RG, relative gamma power; RSMR, relative sensorimotor rhythm; RSMT, ratio of sensorimotor rhythm-mid beta to theta; SEF, spectral edge frequency; ${ }^{* * *} p<0.000$.

며 덜 자극 받았음을 확인할 수 있었다. 각 눈의 형태에 따라 뇌 파 지표결과는 통계적으로 유의하였다 $(p<0.000)$.
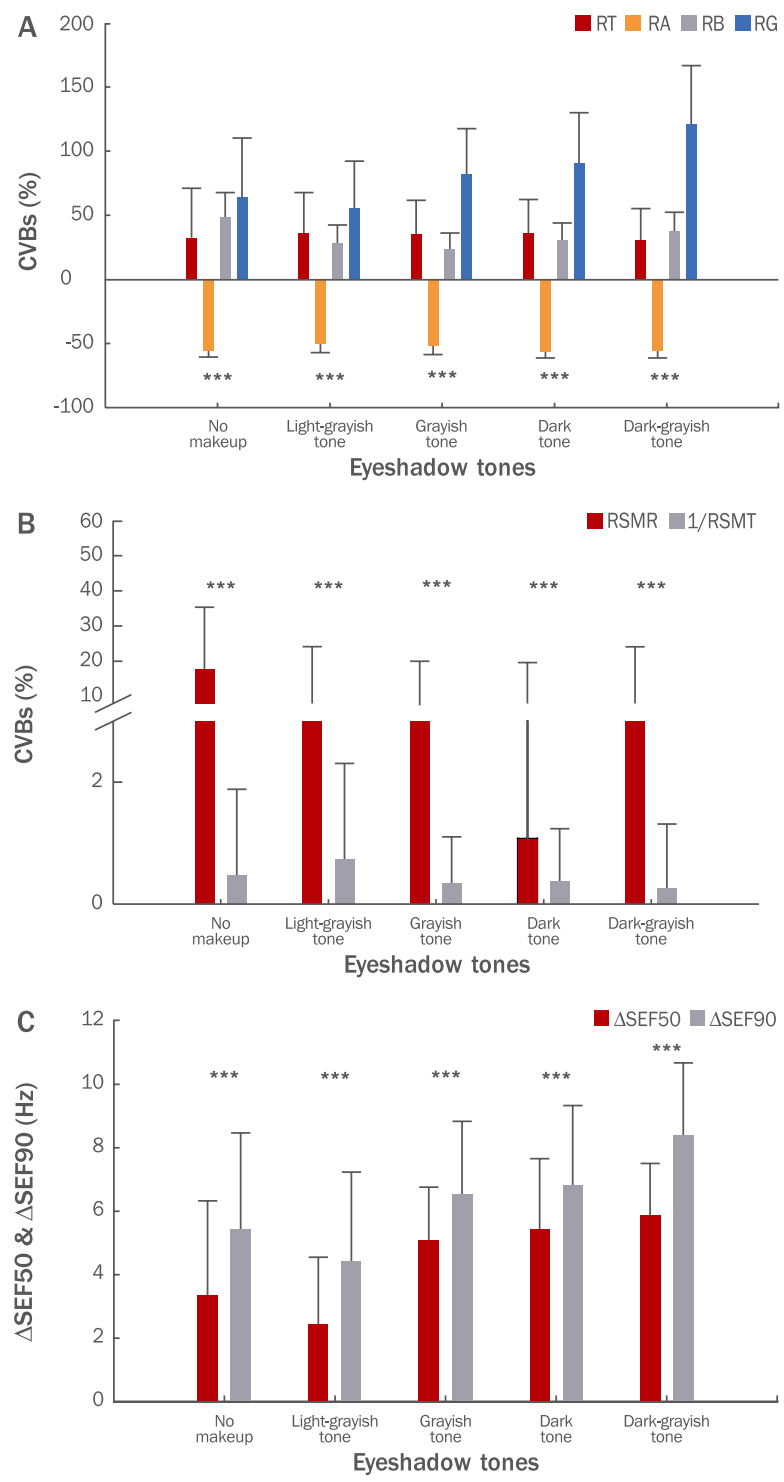

Figure 6. Variation factor of the brainwave according to alterations in the eyeshadow tones in BE.

This result is the brainwave according to stimulus by changing the brightness in BE 5 levels (no makeup, light-grayish tone, grayish tone, dark tone, and dark-grayish tone). The result of the statistical significance according to alterations in eyeshadow tones in $B E$ is shown. (A) CVBs on RT, RA, RB, and RG for the eyeshadow tones in BE. (B) CVBs on RSMR and 1/RSMT for the eyeshadow tones in BE. (C) $\triangle$ SEF50 and $\triangle$ SEF90 for the eyeshadow tones in BE. $\mathrm{BE}$, big eyes; CVB, coefficient of variation for the brainwave; RT, relative theta power; RA, relative alpha power; RB, relative beta power; RG, relative gamma power; RSMR, relative sensorimotor rhythm; RSMT, ratio of sensorimotor rhythm-mid beta to theta; SEF, spectral edge frequency; ${ }^{* * *} p<0.000$.

\section{2. 아이쉐도우 톤 변화에 따른 뇌파 변동 계수}

$\mathrm{SE}, \mathrm{UE}, \mathrm{DE}, \mathrm{SmE}, \mathrm{BE}$ 의 no makeup을 기준으로 lightgrayish tone, grayish tone, dark tone, dark-grayish tone 
으로 명도를 5 단계로 표현한 자극물을 제시하여 뇌파 측정 결과 를 $\mathrm{CVB}$ 로 추출하였다.

$\mathrm{SE}$ 에 톤 변화를 주어 자극물로 제시하여 본 $\mathrm{CVB}$ 에서는

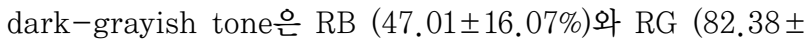
$41.96 \%$ )가 가장 활성되었으며, no makeup의 CVB에서는 SE 자극시 RA가 $-48.91 \pm 5.50 \%$ 로 가장 적게 감소하였다(Figure 2A). SE의 dark tone에서 RSMR이 가장 높게 도출되었고 no makeup에서 1/RSMT가 가장 활성되었다(Figure 2B). $\triangle$ $\mathrm{SEF} 50$ 은 $\mathrm{SE}$ 의 dark tone에서 가장 활성되었으며, $\triangle \mathrm{SEF} 90$ 은 dark-grayish tone에서 가장 활성되었다(Figure $2 \mathrm{C}$ ).

$\mathrm{UE}$ 에 톤 변화를 주어 자극물로 제시하여 본 CVB는 darkgrayish tone일 때 $\mathrm{RB}(62.80 \pm 18.54 \%)$ 와 $\mathrm{RG}$ (95.60土 $47.29 \%$ )가 가장 활성되었다(Figure $3 \mathrm{~A}$ ). 반대로 RA는 darkgrayish tone의 자극물을 제시할 경우 $-69.27 \pm 18.51 \%$ 로 가 장 낮게 활성되었다. RSMR과 $1 / \mathrm{RSMT}$ 는 dark tone에서 각각 $28.80 \pm 25.81 \%, 0.76 \pm 1.45 \%$ 로 높게 출현하였다(Figure 3B). 스트레스를 받을 때 활성되는 $\triangle \mathrm{SEF} 90$ 도 역시 어두운 톤의 dark-grayish tone 자극에서 $5.64 \pm 2.82 \mathrm{~Hz}$ 로 높게 출현되었 으며, no makeup에서는 $\triangle \mathrm{SEF} 90$ 이 $6.20 \pm 2.57 \mathrm{~Hz}$ 로 높게 도 출되었다(Figure $3 \mathrm{C}$ ).

Dark-grayish tone의 $\mathrm{DE}$ 자극에서는 $\mathrm{RB}(38.10 \pm 13.82 \%)$ 와 RG (61.62 $\pm 34.54 \%)$ 의 CVB가 가장 크게 반응하였으며, dark tone의 RB $(38.42 \pm 14.14 \%), \mathrm{RG}(61.34 \pm 35.92 \%)$ 도 dark-grayish tone자극경향과 비슷한 추세로 활성되었다 (Figure 4A), RA의 CVB는 dark tone에서 가장 비활성되었다. $\mathrm{RSMR}$ 은 $\mathrm{DE}$ 의 dark-grayish tone $(8.33 \pm 9.4 \%)$ 에서 가장 높 게 반응하였고, $1 / \mathrm{RSMT}$ 는 dark-grayish tone에서 $0.37 \pm 1.1 \%$ 로 다른 톤보다 가장 낮게 도출되었다(Figure 4B). $\triangle \mathrm{SEF} 50$ 과 $\triangle \mathrm{SEF} 90$ 도 각각 $3.54 \pm 1.96 \mathrm{~Hz}, 4.93 \pm 2.47 \mathrm{~Hz}$ 로 darkgrayish tone의 자극물을 볼 때 가장 높게 도출되었다(Figure 4C).

Dark-grayish tone의 $\mathrm{SmE}$ 자극에 따른 반응은 $\mathrm{RB}$ (32.59 $\pm 12.46 \%)$ 와 RG $(82.47 \pm 42.66 \%)$ 의 $\mathrm{CVB}$ 가 가장 활성되었 다(A). RSMR과 $1 / \mathrm{RSMT}$ 는 grayish tone의 자극시 가장 높게 도출되었다(Figure $5 \mathrm{~B}$ ). $\mathrm{SmE}$ 의 dark tone과 dark-grayish tone에서 $\triangle \mathrm{SEF} 50$ 는 dark tone에서 $\triangle \mathrm{SEF} 90$ 은 darkgrayish tone이 가장 활발하게 활성되었다(Figure $5 \mathrm{C}$ ).

$\mathrm{BE}$ 자극은 dark-grayish tone에서 $\mathrm{RB}(38.25 \pm 14.96 \%)$ 와 $\mathrm{RG}(121.62 \pm 45.80 \%)$ 의 $\mathrm{CVB}$ 가 가장 활발히 반응하였고, RA 는 dark tone에서 가장 비활성되었다(Figure 6A). 1/RSMT의 반응은 저명도의 아이쉐도우 톤에서 감소하였고, 특히 darkgrayish tone에서 가장 낮게 도출되었다(Figure 6B). $\triangle \mathrm{SEF} 50$ 과 $\triangle \mathrm{SEF} 90$ 이 각각 $5.87 \pm 1.61 \mathrm{~Hz}, 8.36 \pm 2.29 \mathrm{~Hz}$ 로 darkgrayish tone의 자극물을 볼 때 가장 높게 활성되었다(Figure
6C). 아이쉐도우의 톤변화에 따라 뇌파 지표는 통계적으로 유의 하였다 $(p<0.000)$.

\section{3. 눈 형태와 아이쉐도우 톤 변화에 따른 감성평가}

다섯 가지 눈 형태의 감성평가는 Figure 7에 도시하였다. $\mathrm{SE}$ 는 soft, static, feminine, strong, brilliant, bright, heavy, silent하다고 평가하였으며, UE는 hard, static, feminine, strong, gloomy, dark, heavy, active하다는 평가였다. $\mathrm{DE}$ 는 soft, static, feminine, week, gloomy, dark, heavy, silent 라고 평가되었으며, $\mathrm{SmE}$ 는 soft, dynamic, feminine, strong, brilliant, bright, light, active라고 평가되었고 $\mathrm{BE}$ 는 hard, static, feminine, strong, gloomy, dark, heavy, silent하다는 평가였다. 눈의 형태에 따른 감성반응은 제 각각의 특성 형태였 다.

$\mathrm{DE}$ 가 $1.68 \pm 2.89$ 로 가장 soft하다는 평가였고, $\mathrm{DE}$ 가 2.18 \pm 2.85 로 static, SE가 $1.94 \pm 2.67$ 로 feminine, UE가 -2.25 \pm 2.23 으로 strong하다는 평가였다. $\mathrm{SmE}$ 가 $1.00 \pm 2.39$ 로 brilliant하다고 하였고, $\mathrm{DE}$ 가 $-2.31 \pm 2.12$ 로 dark하다는 이미

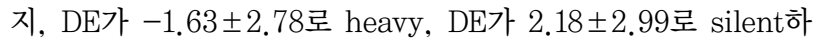
다는 평가였다 $(p<0.000)$.

$\mathrm{SE}$ 의 톤 변화에 따른 감성평가는 고명도의 no makeup에서는 feminine, light, weak, bright하다고 평가하였으며, grayish tone에서는 strong하다는 평가였으며, dark tone과 darkgrayish tone의 자극물을 응시할 경우 strong, hard하다고 평 가하였다(Figure $8 \mathrm{~A}$ ). UE의 감성평가는 dark tone일 경우 반 응이 변하는 시점이었다. 전반적으로 no makeup에서dark tone 으로 톤 변화를 줄 경우feminine한 반응이었다(Figure 8B). $\mathrm{DE}$ 에 톤 변화하여 자극한 감성반응은 light-grayish tone과 grayish tone을 기점으로 변화가 두드러졌다. Light-grayish tone의 DE 자극물의 감성은 week, static, silent하다고 했으나 중명도부터 저명도에 이르는 아이쉐도우 톤에서는 grayish tone 은 weak, dark tone에서 weak, dark-grayish tone은 strong 이라고 평가하였다(Figure $8 \mathrm{C}$ ). $\mathrm{SmE}$ 의 톤 변화에 따른 감성반 응은 light-grayish tone을 기점으로 soft, weak, brilliant, bright하다고 평가되었다(Figure $8 \mathrm{D}) . \mathrm{BE}$ 의 감성평가에서도 light-grayish tone과 grayish tone을 기점으로 감성 변화가 두 드러졌다. 고명도의 light-grayish tone에서 brilliant, bright, light, week하다고 평가하였다(Figure $8 \mathrm{E}$ ). $\mathrm{SE}$ 와 $\mathrm{BE}$ 의 아이쉐 도우 톤 변화에서 감성반응의 편차가 크게 도출되었다. 각각의 눈 형태에 따른 아이쉐도우 톤 변화에 따른 감성반응은 유의하게 도출되었다 $(p<0.000)$. 


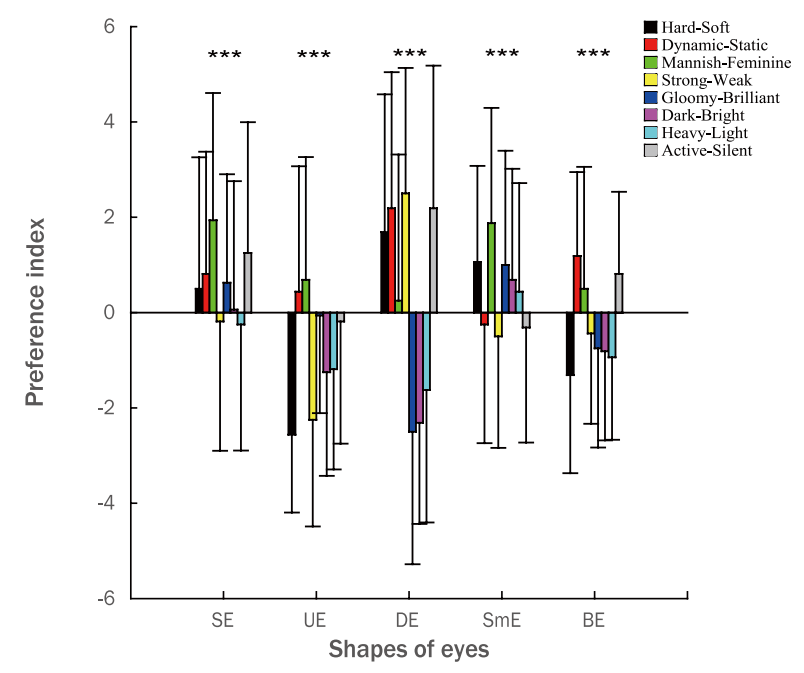

Figure 7. Sensibility response based on the five shapes of eyes.

Sensibility response of SE, UE, DE, SmE, and BE was assessed by a 10 -point scale ( -5 to 5 ) survey questions, which was the criterion. The result of statistically significant emotional responses according to alterations in the shapes of eyes. SE, standard eyes; UE, up-turned eyes; DE, down-turned eyes; SmE, small eyes; BE, big eyes; ${ }^{* * *} p<0.000$.

\section{Discussion}

다섯 가지 눈의 형태 자극물을 보고 측정한 $\mathrm{CVB}$ 는 $\mathrm{UE}$ 와 $\mathrm{BE}$ 의 자극시 $\mathrm{RB}$ 와 $\mathrm{RG}$ 가 활성되었고 $\triangle \mathrm{SEF} 50$ 과 $\triangle \mathrm{SEF} 90$ 이 활 성되었다(Figure 1). 각각의 눈에 아이쉐도우 톤을 단계별로 제 작하여 자극물로 제시한 뇌파 측정 결과는 dark tone과 darkgrayish tone에서 RB와 RG가 활성되었으며 SEF50과 SEF90 이 바탕 뇌파 대비 증가현상이 두드러졌다(Figure 2-6). 각각의 눈에 아이쉐도우 톤을 변하여 만든 이미지 자극의 $\mathrm{CVB}$ 지표 결 과는 no makeup의 눈을 보고 측정한 뇌파 결과보다 편차가 크 게 도출되었다.

선행연구에서 이미지 모양, 크기, 컬러의 3 가지 요소를 대상 으로 시지각 반응에 영향을 미치는 요인 결과는 이들 3 가지 요소 중 컬러에 의한 요인이 가장 큰 것으로 파악되었다(Lee, 2012). No makeup의 눈보다 아이쉐도우 톤이 연출된 이미지 자극에 서 CVB가 높게 도출되었다. 특히 dark-grayish tone의 UE 자 극에서 SEF50과 SEF90의 반응이 높게 형성된 결과는 형태보다 컬러에 의한 반응이 큰 것으로 확인되었다. 눈 형태가 $\mathrm{UE}$ 와 $\mathrm{BE}$ 의 자극에서 $\mathrm{RG}$ 의 상승 폭이 컸고 $\mathrm{DE}$ 보다 $\mathrm{UE}$ 의 형태에서 $\mathrm{RB}$ 와 RG가 활성되었다(Figure 1). 사물을 볼 때 각도가 작은 형태 보다 큰 형태, 내려간 형태보다 올라간 형태, 작은 물체보다 큰 물체, 연한 톤 보다 강하고 진한 톤을 응시할 경우 가독성이 더 높다고 한다(Moon, 2011). 이 결과는 물체의 가독성과 뇌파의
베타파와 감마파와 상관성이 있다고 추정할 수 있었고, 더불어 본 연구에서 no makeup의 눈보다 아이쉐도우 톤이 강하게 연출 된 이미지가 뇌파 반응이 크게 나온 결과를 지지하였다. 본 연구 에서 저명도의 아이쉐도우 톤에 비하여 고명도일 경우 세타파와 알파파가 활성되는 추세였다. Yoto et al. (2007)에 의하면 red, green, blue 색상을 본 뇌파 반응 결과는 고채도의 red에서 베 타파와 감마파가 활성되었으며, 각 색상들이 고명도일 때 세타파 가 상승하였다. 선행 연구에서 red, green, blue의 컬러를 명도 와 채도를 변화시켜 electroencephalography와 event-related potential을 측정한 결과 흥분되는 컬러의 자발뇌파 반응 $(\mathrm{EEG})$ 은 red〉blue>green순으로 나타났고, 각각의 색상의 채도와 명도 를 높인 색상들이 시각유발전위(visual evoked response, VER) 결과가 높게 나타났으며 scalp maps가 넓게 분포되며 활성되었 다(Zhang \& Tang, 2011). 컬러 색상에 의하여 감성과 생체 반 응이 민감하게 변하지만, 채도와 명도를 변화시켜 측정한 뇌파 결과는 활성 폭이 크게 반응하였다.

No makeup의 눈의 형태보다 톤이 첨가된 이미지 자극에 서 모서리 주파수인 SEF50과 SEF90의 상승 결과는 선행연구 (Zhang \& Tang, 2011)의 결과를 통하여 톤에 따른 생리적 변화 가 높다는 것을 지지하였다. 선행연구에서 색은 사람의 집중력에 영향을 주며 특히 명도 변화를 주면 집중력의 효과를 조율할 수 있다고 한다(Lim et al., 2012). 이는 명도 변화에 따른 뇌파 결 과가 유의한 것을 뒷받침하며, 본 연구에서 아이쉐도우 톤 변화 에 따라 뇌파 반응이 변하는 결과임을 나타내었다.

색채에 대한 사람의 감성반응은 명도와 채도에 의하여 좌우 한다는 결과(Kim, 2016)는 본 연구 결과에서 아이쉐도우 톤이 저명도와 고명도일 때에 따라 뇌파와 감성반응 결과가 다양하 게 도출된 결과와 상통하였다. 또 다른 연구에서 visual display terminal에 제시된 심볼 마크의 가독성은 색상의 조합이 높은 선호 색상 조합에서 사건유발전위인 P300의 결과가 빠르게 도출 되었다(Yeh et al., 2013). 이렇듯 선호하거나 집중되는 색상에 서 뇌의 반응이 빠르게 도출되었다.

두 가지 색을 배색했을 때의 색 감정은 단색을 보았을 때 보다 더 만족감이 높았으며 색 감정도 높게 평가되었다(You \& Kwak, 2010). 본 연구에서 no makeup의 자극보다 여러 가지의 아이쉐 도우 색의 배색에 따라 베타와 감마파가 상승한다는 결과를 지지 할 수 있었다. 더불어 감성평가에서도 가벼운 쪽 이미지 형용사 언어보다 무겁고 강하다는 이미지 결과를 지지하였다. 이처럼 눈 의 형태와 아이쉐도우 톤 변화에 따른 감성과 생리적 반응은 얼 굴 이미지 연출시 과학적으로 활용할 수 있는 데이터를 제시하였 다. 

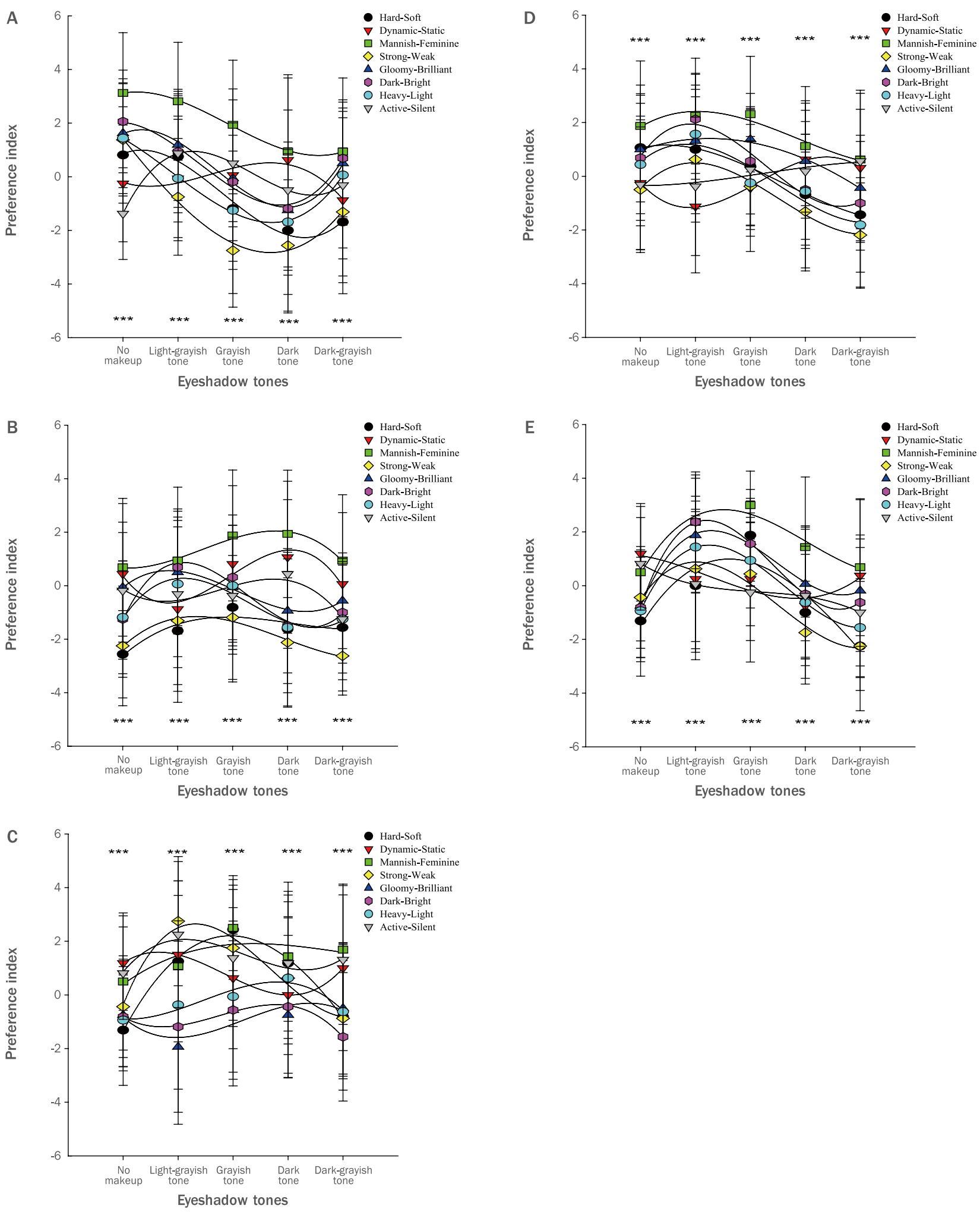

Figure 8. Sensibility response based on alterations in the eyeshadow tones.

Sensibility response of five stimuli, which altered in the five shapes of eyes with no makeup, light-grayish, grayish, dark, and darkgrayish tones, was assessed by a 10-point scale ( -5 to 5$)$ survey questions, which was the criterion. The result of the statistically significant emotional responses according to alterations in eyeshadow tones is shown. (A) SE, (B) UE, (C) DE, (D) SmE, and (E) BE. $\mathrm{SE}$, standard eyes; UE, up-turned eyes; DE, down-turned eyes; SmE, small eyes; BE, big eyes; ${ }^{* * *} p<0.000$. 


\section{Conclusion}

20 대 미용 전공 여성 20 명을 대상으로 다섯 가지의 눈의 형태와 아이쉐도우의 톤을 변화시켜 도출한 뇌파와 감성 결과는 다음과 같 았다. 각성과 자극시 활성되는 RB와 RG, SEF50과 $\mathrm{SEF} 90$ 은 $\mathrm{UE}$ 와 $\mathrm{BE}$ 의 형태에서 활성되었고, 반대로 이완시 활성되는 $\mathrm{RA}$ 는 $\mathrm{SmE}$ 와 $\mathrm{DE}$ 의 형태에서 나타났다. 톤 변화에 따른 뇌파 반응은 저명도인 dark tone과 dark-grayish tone에서 RB, RG가 활성되었고 반대로 이완 지표 $\mathrm{RA}$ 는 비활성되었다. $\mathrm{UE}$ 와 $\mathrm{DE}$ 의 형태에서 감성반응의 편 차가 컸다. 각각 눈 형태에 아이쉐도우 톤 변화 시 감성반응결과는 다소 차이가 있었으나, 저명도인 dark-grayish tone에서 strong, heavy 하다고 평가하였다. 이러한 결과는 눈의 형태에 따라 뇌파와 감성반응이 변화하였으나, 톤에 변화에 따른 뇌파반응 결과가 더욱 크다는 것을 파악할 수 있었다. 특히 가독성과 집중력 향상시 $\mathrm{RB}$ 와 $\mathrm{RG}$ 의 활성이 두드러졌다. 눈의 형태보다 메이크업 톤 변화에 따른 생리 - 감성적 반응이 더 크게 나타남에 따라 메이크업시 아이쉐도우 의 톤 변화에 따라 감성을 다양하게 변화시킬 수 있음을 유추할 수 있었다. 따라서 메이크업을 통하여 원하는 컨셉이나 이미지 연출시 과학적 데이터 근거 표본으로 활용할 수 있을 것으로 사료된다.

\section{Acknowledgements}

본 연구는 2017년도 장안대학교의 연구비 지원으로 수행된 것으로 이에 감사드립니다.

\section{References}

Ahn JH, Kim JD. Theoretical consideration on color therapy. Journal of Naturopathy, 2: 74-82, 2013.

Han HJ. Effects of makeup on facial images of illustrations. Journal of Korea Society of Color Studies, 29: 49-58, 2015.

Hong SK, Kim MK. The color image positioning map according to four seasonal preference of make-up color and skin texture. Asian Journal of Beauty and Cosmetology, 10: 283-289, 2012.

Ji HS, Kim ES. A study on the color coordination of eyeshadow makeup: focused on works of Kendra Stanton in makeup of 'daytime to night', 'special occasion', 'holiday accents', 'seasonal looks' and 'animated characters'. Fashion \& Textile Research Journal, 18: 509-519, 2016.

Jin H, Kim D, Chung S. Response evaluation of physiological signal with preferred color stimulation for the quantitative guide line of color design. Journal of Basic Design \& Art, 13: 489-497, 2012.

Jung SM, Kim MK, Ryu HW. Influence of the concentration of jasmine oil on brain activity and emotions. Journal of Odor and Indoor Environment, 14: 270-278, 2015.

Kang SY, Kim MK, Ryu HW. Influence of the concentration of lavender oil on brain activity. Asian Journal of Beauty and Cosmetology, 11: 1099-1107, 2013.

Kim JS, Ryu JW. Interaction effects of two salient cues on males fashion images: hair lengths \& hair colors. Journal of the Korean Society of Clothing and Textiles, 28: 1320-1328, 2004.

Kim MK, Ryu HW. Analysis of emotional images according to eyes shapes and smoky makeup tone. Science of Emotion \& Sensibility, 14: 321-330, 2011.

Kim MK. Correlation between the factors of personal color diagnosis guide and brain wave analysis. Asian Journal of Beauty and Cosmetology, 14: 407-416, 2016.

Kim MK. The study of emotional reaction affecting the face image according to illustration various form of eyeliner. Asian Journal of Beauty and Cosmetology, 12: 217223, 2014.

Kim YS, Song JH, Cho HJ. Application of eyeshadow colors to bridal makeups according to makeup images. Asian Journal of Beauty and Cosmetology, 13: 425-435, 2015.

Kim YS. A study on make-up image and color preferred by men of 20s 30s. Journal of Korea Society of Color Studies, 25: 55-66, 2011.

Knez I. Effects of colour of light on nonvisual psychological processes. Journal of Environmental Psychology, 21: 201-208, 2001.

Lee AY, Lee SH. The effect of color on human physiological and emotional responses: focusing on brain wave analysis according to color stimulation type. Korea Journal of Counseling, 13: 779-798, 2012.

Lee YJ. A study on the social-psychological characteristics of hybrid make-up. Journal of Psychology and Behavior, 2: 19-29, 2010.

Lee YJ. A study on visual-perception responses to the shape, scale and color of images. Journal of Basic Design \& Art, 13: 263-271, 2012.

Lim JE, Seo BH, Kim SH, Chun SY. Study on EEG feature 
extraction under LED color exposure to enhance the concentration. Advanced Engineering Forum, 2-3: 261$265,2012$.

Moon EB. Color design textbook. Ahn Graphics Publishers, Paju, pp252-282, 2011.

Shahbazi M, Schmidt M, Carruth LL. Distribution and subcellular localization of glucocorticoid receptorimmunoreactive neurons in the developing and adult male zebra finch brain. General and Comparative Endocrinology, 174: 354-361, 2011.

Song MY, Park OL. A study on the perception of face type to color of make up. Journal of the Korean Data Analysis Society, 7: 207-219, 2005.

Song MY, Park OL. A study on the perception of face type to makeup. Journal of the Korean Data Analysis Society, 6: 1543-1557, 2004.

Strochlic DE, Romero LM. The effects of chronic psychological and physical stress on feather replacement in European starlings (Sturnus vulgaris). Comparative Biochemistry and Physiology Part A: Molecular \& Integrative Physiology, 149: 68-79, 2008.

Yeh YY, Lee DS, Ko YH. Color combination and exposure time on legibility and EEG response of icon presented on visual display terminal. Displays, 34: 33-38, 2013.
Yildirim K, Hidayetoglu ML, Capanoglu A. Effects of interior colors on mood and preference: comparisons of two living rooms. Perceptual and Motor Skills, 112: 509524, 2011.

Yoo TS. Development of facial and make-up images scales. Journal of Korea Design Forum, 32: 281-294, 2011.

Yoto A, Katsuura T, Iwanaga K, Shimomura Y. Effects of object color stimuli on human brain activities in perception and attention referred to EEG alpha band response. Journal of Physiological Anthropology, 26: 373-379, 2007.

You C, Kwak Y. Color emotion studies for single colors and two-color combinations using affect adjectives. Journal of the HCl Society of Korea, 5: 19-24, 2010.

Yun $\mathrm{SH}$, Jung $\mathrm{KH}$. Research about relationship between bridal make-up's color and image: with 2015's picturial magazine as the center. Journal of Basic Design \& Art, 17: 401-410, 2016.

Zhang $\mathrm{H}$, Tang $\mathrm{Z}$. To judge what color the subject watched by color effect on brain activity. International Journal of Computer Science and Network Security, 11: 80-83, 2011. 


\section{국문초록}

\section{눈의 형태와 아이쉐도우 톤 변화에 따른 뇌 인지와 감성반응}

김민경

장안대학교 뷰티케어과, 경기도 화성시, 한국

목적: 본 연구는 다섯 가지 눈의 형태[표준형(standard eyes, SE), 올라간 눈(up-turned eyes, UE), 내려간 눈(down-turned eyes, $\mathrm{DE})$, 작은 눈(small eyes, $\mathrm{SmE})$, 큰 눈(big eyes, $\mathrm{BE})]$ 과 아이쉐도우 톤 변화에 따른 뇌 인지 반응을 정량적으로 평가하여 감성반응 과의 상관관계를 파악하여 이미지 메이킹에 과학적 데이터로 활용하고자 한다. 방법: 다섯 가지 눈의 형태와 톤 변화에 따른 자극 물을 제시하여 뇌파 측정을 통한 정량적 데이터를 추출하였고, 감성반응은 어의차이 척도인 10 point scale ( -5 to 5$)$ 을 사용하여 설 문 문항을 구성하였다. 결과: 각성과 자극시 활성되는 상대 베타파와 상대 감마파, SEF50과 SEF90은 UE와 BE의 형태에서 증가 폭이 컸고, 이완시 활성되는 상대 알파파는 $\mathrm{SmE}$ 와 $\mathrm{DE}$ 에서 활성되었다. 톤 변화에 따른 뇌파 반응은 저명도에서 상대 베타파, 상대 감마파, spectral edge frequency 50 (SEF50)과 SEF90이 활성되었다. 각각 눈 형태에서 아이쉐도우 톤 변화 시 감성반응 결과는 다 소 차이가 있었으나, 저명도인 dark-grayish tone에서 strong, heavy 하다고 평가하였다. 결론: 눈의 형태보다 아이쉐도우 톤 변화 에 따른 생리 - 감성적 반응이 더 크게 도출됨에 따라 메이크업시 아이쉐도우의 톤 변화에 따라 감성을 다양하게 변화시킬 수 있음 을 확인할 수 있었다. 따라서 메이크업을 통하여 원하는 컨셉이나 이미지 연출시 과학적 데이터 근거 표본으로 활용할 수 있을 것으 로 사료된다.

핵심어: 뇌, 인지, 감성, 눈의 형태, 아이쉐도우 톤

본 연구는 2017년도 장안대학교의 연구비 지원으로 수행된 것으로 이에 감사드립니다.

\section{참고문헌}

강승연, 김민경, 류희욱. 라벤다 오일의 농도변화가 뇌 활성에 미치는 영향. 아시안뷰티화장품학술지, 11: 1099-1107, 2013.

김민경, 류희욱. 눈 형태에 따른 스모키 메이크업의 감성 이미지. 감성과학, 14:321-330, 2011.

김민경. 다양한 아이라이너의 형태의 일러스트레이션이 얼굴 이미지에 미치는 감성반응 효과. 아시안뷰티화장품학술지, 12: 217-223, 2014.

김민경. 퍼스널 컬러진단 가이드 요인간 상관관계와 뇌파분석. 아시안뷰티화장품학술지, 14: 407-416, 2016.

김양순, 송정화, 조현주. 이미지별 메이크업에 따른 신부메이크업 연출을 위한 아이새도우 컬러 적용. 아시안뷰티화장품학 술지, 13: 425-435, 2015.

김영숙. 20 30대 남성이 선호하는 여성의 메이크업 이미지와 색채에 관한 연구. 한국색채학회논문집, $25: 55-66,2011$. 김재숙, 류지원. 헤어 길이와 헤어 컬러가 남성의 패션 이미지에 미치는 상호작용효과. 한국의류학회지, 28: 1320-1328,

2004.

문은배. 색채 디자인 교과서. 안그라픽스, 파주, pp252-282, 2011.

안지혜, 김종두. 컬러테라피에 대한 이론적 고찰. 한국자연치유학회지, 2: 74-82, 2013.

유찬양, 곽영신. 감정 형용사를 이용한 단색과 두색 배색의 색감정 연구. 한국HCI학회 논문지, 5: 19-24, 2010.

유태순. 화장 전과 후의 얼굴이미지 측정도구개발. 한국디자인포럼, 32: 281-294, 2011.

윤세희, 정강화. 신부메이크업 색채와 이미지의 상관관계에 관한 연구: 2015 년 잡지화보를 중심으로. 기초조형학연구, 17: 401-410, 2016. 
이애영, 이선화. 컬러가 인간의 생리 - 정서적 반응에 미치는 효과: 컬러 자극유형에 따른 뇌파분석을 중심으로. 상담학연 구, 13: 779-798, 2012.

이윤정. 이미지(형, 크기, 컬러)의 시지각 반응에 관한 연구. 기초조형학연구, 13: 263-271, 2012.

이윤정. 하이브리드 메이크업의 사회 심리적 특성 연구. 심리행동연구, 2: 19-29, 2010.

정소명, 김민경, 류희욱. 자스민 농도변화가 뇌활성과 감성에 미치는 영향. 실내환경 및 냄새 학회지, $14: 270-278$, 2015.

지현숙, 김은실. 아이새도우 메이크업(Eye-shadow Makeup)의 컬러 배색에 관한 연구: 켄드라 스탠튼(Kendra Stanton) 의 “내추럴(Daytime to Night)", “스페셜(Special Occasion)", “할러데이(Holiday Accents)", "시즌(Seasonal Looks)", "캐릭터(Animated Characters)" 메이크업 경우를 중심으로. 한국의류산업학회지, 18: 509-519, 2016.

진혜련, 김동욱, 정성환. 컬러디자인의 정량적 가이드라인 설정을 위한 선호컬러자극에 따른 인체생리신호반응평가. 기초 조형학연구, 13: 489-497, 2012.

한혜진. 일러스트레이션 얼굴 이미지의 메이크업 색채 효과. 한국색채학회논문집, 29: 49-58, 2015.

홍수경, 김민경. 사계절 메이크업 색상 선호도와 피부의 질감변화에 따른 색상 이미지 포지셔닝 맵. 아시안뷰티화장품학술 지, 10: 283-289, 2012. 


\section{中文摘要}

\section{根据眼型和眼影色彩大脑识别和感性反应}

金玟京

长安大学美容学科, 京畿道华城市, 韩国

目的: 根据5种眼型即标准型（standard eyes, SE）、吊眼（up-turned eyes, UE）、垂眼（down-turned eyes, DE）、小眼（small eyes, SmE）和大眼（big eyes, BE）以及眼影色调变化，定量评价大脑识别反应， 探索与感性反应的相关性, 将作为图像制作方面的科学数据使用。方法: 提供5种眼型和色调变化的刺激物, 通 过脑波测定, 定量提取数据。感性反应通过语义差异的10 point scale（一-5至5）组成的问卷项目来评价。结 果: 在警戒和刺激时激活的相对 $\beta$ 波和相对 $\gamma$ 波, spectral edge frequency 50 (SEF50) 以及SEF90, 在UE和 $\mathrm{BE}$ 形态中, 其增加幅度比较大, 而松弛时激活的相对 $\alpha$ 波在SmS和DE中激活。色调变化的脑波反应显示: 在 低亮度中, 相对 $\beta$ 波和相对 Y波, SEF50, SEF90激活。在不同眼型中, 分别进行色调变化时, 感性反应稍有差 异, 但低亮度dark-grayish tone中被视为强烈而重。结论: 分析表明, 生理和情绪反应更多地来源于眼影变化 而不是眼型, 因此可以看出, 根据化妆时眼影的色调变化, 表现各种感性反应。通过化妆创造理想的概念或图 像时, 它可以作为科学数据样本使用。

关键词: 脑, 识别, 感性, 眼型, 眼影色调 